\title{
The Driving Way of Organizational Culture to the Connotative Development of Private Higher Learning Institution
}

\author{
Jun Luo \\ Department of Management \\ Guangdong University of Science \& Technology \\ Dongguan, China 523083
}

\author{
Yefu Tang \\ Department of Management \\ Guangdong University of Science \& Technology \\ Dongguan, China 523083
}

\author{
Yulan $\mathrm{Yu}^{*}$ \\ Department of Psychology/ Research Center for Quality of \\ Life and Applied Psychology \\ Guangdong Medical University \\ Dongguan, China 523808 \\ *Corresponding author
}

\begin{abstract}
Private higher learning institution is an important force of higher education in China, but at present the concept of the family and the students to them and the fierce competition mode of enrollment are basically at a disadvantage. If private higher learning institution would like to get sustainable development under the background of the competition in the face of education industrialization, it should build its own unique organizational culture system from the cultural control system (hard power) and cultural cohesion system (soft power), Differentiate with competitors, form a unique core competitiveness, promote the connotative development.
\end{abstract}

Keywords-Private higher learning institution; organizational culture; connotative development

\section{INTRODUCTION}

In order to make up for the shortage of higher education resources and make full use of private capital in China, higher education reform introduced the concept of "education industrialization", so private higher learning institution has become an important force in China's higher education. There were a total of 2845 colleges and universities by May 21, 2015 and it is estimated that the number of the national college entrance examination will gradually reduce from 2016, and people don't think highly of private colleges and universities. Therefore, private higher learning institution must shape its own core competitiveness, if it wants to develop in the competitive market of the education industry. Private colleges and universities should try to form their own characteristics from the aspect of

Education and teaching reform project of higher education in Guangdong Province (2016258); Innovation and strength school project Guangdong University of Science \& Technology in 2015 (GKY2015CQYB-2); Guangdong Adult Education Association adult education research program (key projects) (Ycx161008) culture characteristics, take different competitive strategy, form a unique core competitiveness and promote the connotative development.

\section{The PRESENT SituAtion OF ORGANIZATIONAL}

\section{CULTURE IN PRIVATE HIGHER LEARNING INSTITUTION}

Private higher learning institution refers to institutions of higher learning and other educational institutions, which are organized by enterprises, institutions, social organizations, other social organizations and citizens, and use the non-state financial education funds. Its nature is actually the nature of the operation of the enterprise, self financing model, so "the systems and files" of the private colleges and universities are relatively perfect and mature since they were built because they have the original business management experience. Managers do their own things, such as, preparing for documents, developing systems, requiring employees, even some managers develop their own documents for personal and departmental interests and don't care the overall interests of the organization. Everything seems to be in the hands of the people from the files and system. And the core members of the management, front-line teachers are doing their own thing, such as lesson preparation and teaching. Managers and being managed are staying with each other but they have no same ideal for the university for a long time. Managers just do files and care about what are "the files", but don't care about their reasonableness and effectiveness, even reverse the nature of the system, that is regulation and incentive system. The campus is filled with a kind of organizational culture that is "you are good, I am good and everyone is good", "you don't take seriously, I do not take seriously". All these deviate from the connotation of the school organizational culture. School organization culture refers to the formation and establishment of the ideological 
achievements and spiritual strength in the long-term school running practice, including all members of the school have the similar ideas, values, beliefs and life, for the basic views of the internal and external environment of school. It reflects the common pursuit of school organization community, common values and common interests. It penetrates thoughts into all members of the school by culture, an invisible sword, shapes the organizational cohesion concept, makes individuals identity to the organization, so as to combine personal goals and school collective goals, and then transform the organization. as an invisible hand to form a very fruitful management organization.

\section{The SignificANCE OF CONSTRUCTING A UNIQUE ORGANIZATIONAL CULTURE IN PRIVATE HIGHER LEARNING} INSTITUTION

\section{A. The Construction of Organizational Culture Is Helpful to Improve the Management Level of Colleges and Universities}

Under the background of "education industrialization", private higher learning institution, as a social organization, have the nature of organization operation. In the existing management mode, the traditional management mode of empiricism is taking, which is lack of scientific nature. And modern scientific management mode is lack of "peopleoriented" idea, which ignores the people's subjective initiative and flexibility in colleges and universities. Therefore, shaping the management model of organizational culture embodies the "people-oriented", which means that people are the enormous potential of the organization resources and people's heart and spirit should be respected, and then common identity values would be formed. When colleges and universities achieve unified management of "administrative control" and "culture oriented", it is benefit to the management of colleges and universities.

\section{B. Unique Organizational Culture Is Conducive to the Formation of the Core Competitiveness of Colleges and Universities and Promotes the Development of Connotation}

The brand image of the private college and university is a complex, which is composed of "hardware" (serving students) and "software" (organizational culture) in the eyes of the public. The unique characteristics of private higher learning institution organization culture can have a tremendous brand, form their own core competitiveness, strengthen the internal members (managers, teachers and students) and external parts ( the emotion and cognition of family, public to college and university), create a strong brand, enhance virtually the competitiveness of private higher learning institution, and then promote their connotative development.

\section{The Construction of Organizational Culture in Colleges and Universities Is Conducive to Promoting the Reform of Higher Education}

China's higher education and the modern education system has been in constant development and reform, but the internal management of colleges and universities has been hindering the development of China's higher education, such as the current title evaluation model, the evaluation system of the internal organization of colleges and universities, etc.. The system always varies from person to person, including the coming and going of the employees in the organization, the transfer of roles and positions, and even the replacement of the school leaders. All these will stifle the enthusiasm of many teachers and hinder the development of Higher Education. The cultural construction of the organization shapes ultimately a recognition of the organization values, a unified values affecting the behavior and spirit of all members of the school, a mission of education for higher education.

\section{School Organizational Culture Is Benefit to the Construction of Harmonious Campus Culture}

Campus culture of college and university is an important factor which influences the development of the school's benign and orderly development. Positive energy of the campus culture can shape the organizational culture and promote the reform and development of colleges and universities. Organizational culture management emphasizes human-centered, pay attention to the value of employees, focus on the relationship of team spirit and cooperation consciousness. Such culture will unite organization and form a centripetal force, adjust the consistency of personal goals and organizational goals, and strive to achieve the ultimate goal, and then a harmonious campus will be built.

\section{EFFECTIVE WAYS TO BUILD A UNIQUE Organizational CULTURE IN PRIVATE HIGHER LEARNING INSTITUTION}

The basic path of private higher learning institution to build a unique organizational culture can be constructed from two aspects, the cultural control system (hard power) and cultural cohesion system (soft power). However, the formation of the significant factors of cohesive force in the organizational culture system determines the unique function of the school organizational culture.

\section{A. Cultural control system}

The control system includes standardization system, control system and responsibility system.

1) Standardization system: Standardization is the foundation of scientific management. Private higher learning institution is an important social development industry, and its socialization degree is higher and higher. What's more, the scale of colleges and universities is getting bigger and bigger and professional setting is getting smaller and smaller. At the same time the cooperation between universities and enterprises is becoming wider and wider. Then, scientific standards should be developed to insure different departments work orderly for connection and coordination to maintain effective and smooth, efficient operation of the formation of standard system. Such as, the organizational structure of private higher learning institution, management rules and regulations, departmental 
responsibilities, work instructions, a variety of operational processes, forms, data, etc...

2) Control system: Control system is an arrow to maintain the operation of the organization legitimacy, rationality, and the effectiveness. Usually, it is the establishment of the constraints between the various departments within the organization, between the various persons in the work, between the various processes. In addition to vertical management of the organization, the organization is the internal management of the horizontal. For higher learning institution, the Ministry of Education is on the constraints of the professional departments, Personnel Department is on the constraints of the various branches, Financial Department is on the constraints of sections, etc...

3) Responsibility system: Standardization system is the starting point and foundation of effective management of university organization and benign control, and no control system standard is like the water without a source. The control system is the process of management control. If there is no effective control of the process, there is no effective results. Responsibility system is the result of management control. The three systems are interdependent and indispensable and they form a systematic, standardized, detailed control culture.

\section{B. Cultural Cohesion System}

The cultural cohesion system includes three parts, value system, team building and internal culture.

1) Value system: It refers to the common values of the employees in the organization and includes the transformation of values, employee career planning, employee interaction mechanism, organizational management policies and guidelines.

2) Team building: It refers to the team or the construction of management team of the organization in the management of the business activities and includes staff recruitment mechanism, staff training mechanism, personnel training mechanism, the construction of professional team, the management of cadres to enhance the leadership mechanism.

3) Internal culture: It refers to the atmosphere of the work and life in the process of activities of the organization and management. It includes the staff committee and the reward and punishment mechanism, recreational activities, publications, employee handbook, responsibility mechanism and abnormal communication and feedback mechanism.

These three parts are complementary and indispensable. Value system emphasizes the idea of organization and it is the ideological basis of the organization. Team building stresses is team and it is the core of organization and also the material basis of organization in business activities. Internal culture emphasizes the shape of working and living environment and it is the foundation of environmental organization in business activities. Value system and internal culture are the guarantee of team building, and team building is the carrier of value system and internal culture. Value system and internal culture will become nothing without team construction. Therefore, the value system and internal culture are the cohesion, and team building is the fundamental cohesion.

\section{CONCLUSION}

The organizational culture is an indispensable part in the development of private higher learning institution. Each school has its own unique resources and it should utilize and allocate resources reasonably. And then private higher learning institution build its own unique organizational culture system from the cultural control system and cultural cohesion system, which can form cohesive force and centripetal force on the inside and build its own core competitiveness on the outside and it is benefit to the development of connotation of private higher learning institution.

\section{REFERENCE}

[1] Zheng li, Yan Xinping, The significance and approach of the organization culture construction in colleges and universities from the perspective of organizational culture theory[J], Education and Occupation, 2008,30:40-41.

[2] Wang Xueqi, The role of organizational culture in the development of private colleges and universities[J], Cooperative economy and Technology, 2013,9:118-119. 